DOI: https://doi.org/10.24127/ajpm.v10i4.4271

\title{
EFEKTIVITAS PROBLEM-BASED LEARNING SETTING STAD DITINJAU DARI HASIL BELAJAR DAN DISPOSISI MATEMATIS MAHASISWA
}

\author{
Maria Trisna Sero Wondo ${ }^{1 *}$, Konstantinus Denny Pareira Meke ${ }^{2}$, Sofia Sao $^{3}$ \\ ${ }^{1,2,3}$ Universitas Flores, Ende, Indonesia \\ *Corresponding author. Email: trisnawondo@gmail.com,86316, Ende, Indonesia. \\ E-mail: trisnawondo@gmail.com ${ }^{1 *)}$ \\ dennypareira@uniflor.ac.id $^{2)}$ \\ saosofia@gmail.com $^{3)}$
}

Received 22 September 2021; Received in revised form 16 November 2021; Accepted 28 December 2021

\begin{abstract}
Abstrak
Masalah yang ditemukan dalam penelitian ini ialah model pembelajaran dalam mata kuliah Teori bilangan yang digunakan belum tepat hingga menyebabkan kurang maksimalnya hasil belajar dan ranah afektif mahasiswa. Tujuan dalam penelitian ini ialah untuk mengukur efektivitas problem-based learning setting STAD ditinjau dari hasil belajar dan disposisi matematis. Penelitian ini merupakan penelitian eksperimen jenis pre-exsperimental. Penelitian pre eksperimen ini menggunakan desain one-group pretest-posttest design dengan populasi mahasiswa semester II Program Studi Pendidikan Matematika Universitas Flores tahun akademik 2020/2021. Sampel dalam penelitian ini adalah satu kelas mahasiswa semester II. Instrumen penelitian yang digunakan adalah tes hasil belajar dengan bentuk soal uraian sebanyak 6 soal dan non tes berupa angket disposisi matematis berbentuk skala likert dengan lima pilihan jawaban. Teknik analisis data yang digunakan yaitu uji paired sample $t$ test dengan bantuan SPSS Windows Version 16. Berdasarkan hasil uji, diperoleh nilai sig. sebesar 0,00 untuk hasil belajar dan disposisi matematis. Hasil tersebut mendeskripsikan bahwa problem-based learning setting STAD efektif serta baik untuk diterapkan dalam rancangan proses pembelajaran pada matakuliah teori bilangan, dtinjau dari hasil belajar dan kemampuan disposisi matematis
\end{abstract}

Kata kunci: Disposisi matematis; hasil belajar; PBL setting STAD

\begin{abstract}
The problem found in this study is that the learning model in the number theory course used is not appropriate, causing less than optimal learning outcomes and students' affective domains. This study aims to describe the effectiveness of the STAD problem-based learning setting in terms of learning outcomes and mathematical dispositions. This research is an experimental research type of preexperimental. This pre-experimental study used a one-group pretest-posttest design with a population of students in the second semester of the Mathematics Education Study Program at the University of Flores for the 2020/2021 academic year. The sample in this study was a class of second-semester students. The research instrument used was a test of learning outcomes in the form of a description of 6 questions and a non-test in the form of a mathematical disposition questionnaire in the form of a Likert scale with five answer choices. The data analysis technique used was the paired-sample t-test with the help of SPSS Windows Version 16. Based on the test results, obtained the value of sig. of 0.00 for learning outcomes and mathematical dispositions. This result shows that the problem-based learning setting of STAD is effective and good to be applied in the design of the learning process in a number theory course, in terms of learning outcomes and mathematical disposition abilities.
\end{abstract}

Keywords: Learning outcomes; mathematical disposition; PBL setting STAD

This is an open access article under the Creative Commons Attribution 4.0 International License 
DOI: https://doi.org/10.24127/ajpm.v10i4.4271

\section{PENDAHULUAN}

Teori bilangan adalah mata kuliah yang wajib yang ditempuh oleh mahasiswa Pendidikan Matematika. Teori bilangan merupakan konsep dasar dalam mempelajari beberapa cabang ilmu matematika lainnya. Tidaklah heran jika dalam olimpiade matematika konsep dari teori bilangan selalu dimunculkan. Oleh karena itu, bagi yang berminat untuk mendalami olimpiade matematika, perlu sekali untuk mempelajari konsep dari teori bilangan (Mahmudah \& Triyana, 2018). Begitu juga dengan mahasiswa Program Studi Pendidikan Matematika, yang output nya disiapkan untuk menjadi guru yang siap bersaing di era globalisasi. Namun pada kenyataannya tidak berbanding lurus dengan apa yang diinginkan. Berdasarkan hasil yang diperoleh, terlihat bahwa hasil belajar yang diperloleh mahasiswa masih belum optimal.

Hasil belajar pada dasarnya adalah hasil akhir yang diharapkan dapat dicapai setelah seorang belajar (Sarmiati et al., 2019). Upaya untuk memperoleh hasil belajar dapat dilakukan evaluasi atau penilaian yang merupakan tindak lanjut atau cara untuk mengukur tingkat penguasaan siswa (Nurmila et al., 2019).

Selain menyebabkan nilai mata kuliah rendah, faktor tersebut juga berpengaruh pada ranah afektif, salah satunya yaitu disposisi matematis. NCTM (2000) berpendapat bahwa disposisi matematis sebagai kecenderungan siswa dalam berpikir dan bertindak secara tepat. Kecenderungan tersebut dicerminkan oleh ketertarikan siswa dan kepercayaan diri siswa dalam menyelesaikan masalah matematika, kemauan untuk mencari alternatif penyelesaian, ketekunan dalam menyelesaikan permasalahan, dan kemauan untuk merefleksikan pemikiran mereka sendiri ketika belajar matematika (Mahmuzah et al., 2014).

Salah satu faktor dari belum maksimalnya hasil belajar dan aspek afektif siswa adalah perencanaan dan penggunaan model pembelajaran yang belum cermat. Untuk mengatasi masalah tersebut, perlu adanya strategi atau metode dalam proses pembelajaran yang dirancang oleh dosen yang mampu melibatkan mahasiswa secara aktif. Salah satu strategi yang dapat diterapkan adalah Problem-Based Learning (PBL). PBL merupakan model pembelajaran yang menggunakan masalah-masalah di tahap awal pembelajaran yaitu pada tahap orientasi siswa pada masalah (Kurniyawati et al., 2019). PBL menitikberatkan proses pembelajaran untuk berpusat dan memecahkan masalah. Hal ini senada dengan pendapat dari Fogarty (Chen, 2013) yang menyatakan bahwa PBL sebagai model pembelajaran yang fokus pada masalah nyata. Dalam banyak sumber disebutkan bahwa PBL memiliki keunggulan terutama dalam melatih kemampuan berpikir siswa (Jailani et al., 2017), serta mengembangkan kompetensi siswa pada sejumlah ranah afektif seperti karakter (Jailani et al., 2017). PBL merupakan suatu pendekatan yang berpusat pada siswa dari sebagai pendengar penerima informasi pasif menjadi aktif, mengembangkan masalah, dan keterampilan memecahkan masalah (Ali et al., 2010). Berdasarkan pendapat para ahli dapat disimpulkan bahwa PBL merupakan pembelajaran yang dimulai dengan penyajian masalah yang dapat membantu siswa mengembangkan kemampuan dalam berpikir dan memecahkan masalah. 
DOI: https://doi.org/10.24127/ajpm.v10i4.4271

Beberapa tipe model pembelajaran kooperatif yang efektif adalah tipe Student Teams Achievement Division (STAD). Pembelajaran kooperatif tipe STAD merupakan pembelajaran kooperatif yang sederhana dan mudah dipahami, siswa berkolaborasi dalam grup kecil yang heterogen untuk mempelajari berbagai materi, kemudian siswa diberi kuis untuk mengetahui kemajuan individu. STAD mempunyai lima poin utama dalam proses penerapannya yakni: berkolaborasi dalam grup, penilaian kemajuan secara individual, presentasi kelas, kuis, pemberian reward kepada grup (Yusuf, Natsir \& Hanum, 2005).

Berdasarkan potensi yang dimiliki PBL setting STAD, diharapkan untuk mampu mengatasi permasalahan yang dihadapi sehingga diduga dapat meningkatkan hasil belajar Teori Bilangan dan disposisi matematis mahasiswa pendidikan matematika Universitas Flores.

Terkait dengan penerapan PBL, beberapa penelitian telah dilakukan untuk mengungkap dampak PBL dengan setting kooperatif tipe STAD terhadap pembelajaran. Penelitian yang dilakukan oleh (Armita, U.Y., Marsigit, 2016) yang menyatakan bahwa model PBL setting STAD efektif ditinjau dari prestasi, berpikir kritis, dan selfefficacy. Hasil penelitian (Wicaksono \& Agustyaningrum, 2018) menyatakan bahwa pendekatan PBL dengan setting kooperatif tipe STAD efektif ditinjau dari kemampuan literasi matematis. Hasil penelitian tersebut mengindikasikan bahwa PBL setting kooperatif tipe STAD memberikan kontribusi positif terhadap pembelajaran, namun penelitianpenelitian tersebut belum menyelidiki terkait efektivitas PBL setting kooperatif STAD ditinjau dari hasil belajar dan disposisi matematis mahasiswa. Untuk itu, penelitian ini bertujuan untuk mendeskripsikan efektivitas problem-based setting STAD ditinjau dari hasil belajar dan disposisi matematis.

\section{METODE PENELITIAN}

Penelitian ini masih menggunakan jenis penelitian preeksperimen. Ini berarti bahwa dalam penelitian ini masih terdapat variabel lain yang mempengaruhi penilaian terhadap variabel dependen. Penelitian ini melibatkan satu kelompok eksperimen yang diberikan perlakuan. Kelompok eksperimen dalam penelitian merupakan kelompok mahasiswa yang akan diajar menggunakan model PBL setting kooperatif tipe STAD. Penelitian ini dilaksanakan pada mahasiswa semester II program studi pendidikan matematika, pada bulan Mei sampai Juni tahun 2021. Penelitian ini mengggunakan one-group pretestpostest design.

Variabel penelitian ini adalah (1) PBL dengan setting kooperatif tipe STAD yang digunakan dalam pembelajaran Teori Bilangan (2) hasil belajar yaitu skor total yang diperoleh mahasiswa dalam aspek kognitif pada pembelajaran teori bilangan; (3) disposisi matematis yaitu skor yang diperoleh mahasiswa setelah mengisi angket disposisi matematis.

Populasi dalam penelitian ini adalah mahasiswa semester II Program Studi Pendidikan Matematika Universitas Flores Ende tahun akademik 2020/2021. Dikarenakan hanya terdapat satu kelas, maka kelas tersebut langsung dijadikan sebagai sampel dalam penelitian dengan jumlah mahasiswa sebanyak 20 orang.

Penelitian ini dijalankan dengan prosedur sebagai berikut; 1) menyusun 
instrumen penelitian (tes hasil belajar dan angket disposisi matematis) dan perangkat pembelajaran (Rencana Pembelajaran Semester dan Lembar Kegiatan Mahasiswa), 2) meminta ahli untuk memvalidasi instrumen penelitian, 3) melaksanakan uji coba instrumen penelitian, 4) validasi instrumen penelitian, 5) estimasi reliabilitas instrumen penelitian, 6) melakukan revisi instrumen penelitian, 7) memberikan angket disposisi matematis untuk diisi oleh mahasiswa sebelum pretest, 8) memberikan pretest hasil belajar sebelum diberikan perlakuan, 9) melakukan pembelajaran menggunakan model PBL setting kooperatif tipe STAD, 10) memberikan angket disposisi matematis untuk diisi oleh mahasiswa sebelum posttest, 11) memberikan posttest hasil belajar setelah diberikan perlakuan, 12) Mengolah dan menganalisis data untuk memperoleh hasil penelitian

Teknik pengumpulan data yang digunakan dalam penelitian ini adalah tes dan non tes. Tes diberikan untuk mengukur hasil belajar mahasiswa, sementara non tes (angket) digunakan untuk mengukur kemampuan disposisi matematis mahasiswa. Tes hasil belajar mahasiswa dan angket disposisi matematis diberikan sebelum perlakuan (pretest) untuk melihat kondisi awal mahasiswa dan diberikan setelah perlakuan yaitu diterapkannya model PBL setting kooperatif tipe STAD (posttest).

Setelah instrumen tes dan angket disusun, kemudian divaidasi oleh ahli berdasarkan kesesuaian antara itemitem pertanyaan/pernyataan dengan indikator masing-masing instrumen (validitas isi). Instrumen yang telah divalidasi selanjutnya dilakukan uji coba untuk mengestimasi koefisien reliabilitas dan bukti validitas konstruk.
Data yang diperoleh dalam penelitian ini semua diolah dan dianalisis dengan menggunakan uji paired sample t-test. Lebih lanjut keefektifan perlakuan diuji dengan menggunakan Paired sample $t$ test dengan melihat keadaan perbedaan ratarata sebelum dan sesudah perlakuan (Ismawati \& Prasetyo, 2020). Hipotesis yang digunakan dalam penelitian ini ialah;

\section{Perumusan hipotesis}

1. $\mathrm{H}_{0}$ : pembelajaran dengan model PBL setting kooperatif tipe STAD tidak efektif ditinjau dari hasil belajar mahasiswa pada mata kuliah teori bilangan

$\mathrm{H}_{\mathrm{a}}$ : pembelajaran dengan model PBL setting kooperatif tipe STAD efektif ditinjau dari hasil belajar mahasiswa pada mata kuliah teori bilangan

2. $\mathrm{H}_{0}$ : pembelajaran dengan model PBL setting kooperatif tipe STAD tidak efektif ditinjau dari disposisi matematis mahasiswa pada mata kuliah teori bilangan

$\mathrm{H}_{\mathrm{a}}$ : pembelajaran dengan model PBL setting kooperatif tipe STAD efektif ditinjau dari disposisi matematis mahasiswa pada mata kuliah teori bilangan

\section{Dasar pengambilan keputusan}

1. Jika Asymp sig $<0,05$ maka $\mathrm{H}_{0}$ ditolak

2. Jika Asymp sig $<0,05$ maka $\mathrm{H}_{0}$ ditolak

\section{Uji validitas dan Reliabilitas Instrumen}

1. Tes Hasil Belajar

Uji validitas Instrumen Tes Hasil belajar (THB) menggunakan validitas isi. Lebih lanjut, uji reliabilitas THB, dilihat dari nilai korelasi Guttman split half coefecien. Berdasarkan hasil perhitungan uji reliabilitas, diperoleh nilai korelasi Guttman split half 
coefecien $0,594>\mathrm{r}_{\text {tabel }}(0,456)$ maka disimpulkan bahwa instrumen ini reliable dan layak untuk digunakan dalam penelitian.

2. Angket Disposisi Matematis

Untuk instrumen angket dilakukan uji validitas (isi dan konstruk) dan reliabilitas. Validitas konstruk dilihat dari angka corrected item-total coorelation yang merupakan korelasi antara skor item dengan skor total item (nilai $\mathrm{r}_{\text {hit }}$ ) dibandingkan dengan nilai $r_{\text {tabel. }}$ Jika $r_{\text {hit }}>r_{\text {tabel }}(\operatorname{sig}=0,05)$ maka item tersebut valid. Berdasarkan hasil nilai $r_{\text {hit }}$ dari setiap item $>r_{\text {tabel }}(0,456)$ maka dapat disimpulkan instrumen ini valid.

Pengujian reliabilitas dilihat dari nilai korelasi Guttman split half coefecient $0,854>\mathrm{r}_{\text {tabel }}(0,456)$ maka disimpulkan bahwa instrumen ini reliabel.

\section{HASIL DAN PEMBAHASAN}

Hasil belajar dan nilai disposisi matematis masing-masing diperoleh dari tes hasil belajar dan angket disposisi matematis. Berikut disajikan tabel uji normalitas (Tabel 1 dan Tabel 2) dan homogenitas data (Tabel 3 dan Tabel 4).

Tabel 1. Uji normalitas tes hasil belajar

\begin{tabular}{ccccccc}
\hline \multirow{2}{*}{ Data } & \multicolumn{3}{c}{ Kolmogorov-Smirnov $^{\text {a }}$} & \multicolumn{3}{c}{ Shapiro-Wilk } \\
\cline { 2 - 7 } & Statistic & df & Sig. & Statistic & df & Sig. \\
\hline Pretest & 0,187 & 20 & 0,066 & 0,950 & 20 & 0,372 \\
Posttets & 0,105 & 20 & 0,200 & 0,955 & 20 & 0,442 \\
\hline
\end{tabular}

Berdasarkan hasil output pada

Tabel 1, dapat diketahui nilai signifikansi pretest dan posttest pada tes hasil belajar > 0,05. Hal ini berarti bahwa data yang diperoleh berdistribusi normal.

Tabel 2. Uji normalitas disposisi matematis

\begin{tabular}{ccccccc}
\hline \multirow{2}{*}{ Data } & \multicolumn{3}{c}{ Kolmogorov-Smirnov $^{\mathrm{a}}$} & \multicolumn{3}{c}{ Shapiro-Wilk } \\
\cline { 2 - 7 } & Statistic & df & Sig. & Statistic & df & Sig. \\
\hline Pretest & 0,101 & 20 & 0,200 & 0,965 & 20 & 0,652 \\
Posttets & 0,115 & 20 & 0,200 & 0,956 & 20 & 0,468 \\
\hline
\end{tabular}

Berdasarkan hasil output pada Tabel 2, dapat diketahui nilai signifikansi pretest dan posttest pada disposisi matematis $>0,05$ yang berarti data berdistribusi normal.

Tabel 3. Uji Homogenitas tes hasil belajar

\begin{tabular}{lcccc}
\hline & F & df1 & df2 & Sig. \\
\hline Pretest & 8,293 & 1 & 38 & 0,057 \\
Posttets & 0,000 & 1 & 38 & 0,995 \\
\hline
\end{tabular}

Berdasarkan Tabel 3, diketahui nilai signifikansi > 0,05 maka sebagaimana dasar pengambilan keputusan dalam uji homogenitas, dapat disimpulkan bahwa varians data hasil belajar pretest dan posttest adalah sama atau homogen.

Tabel 4. Uji Homogenitas Disposisi Matematis

\begin{tabular}{ccccc}
\hline & F & df1 & df2 & Sig. \\
\hline Pretest & 0,091 & 1 & 38 & 0,765 \\
Posttets & 0,003 & 1 & 38 & 0,957 \\
\hline
\end{tabular}


DOI: https://doi.org/10.24127/ajpm.v10i4.4271

Berdasarkan hasil yang diperoleh pada Tabel 4, diketahui nilai signifikansi lebih dari 0,05. Hal ini berarti varians data disposisi matematis pretest dan posttest homogen.

Lebih lanjut, karena baik data pretest, posttest maupun data disposisi matematis memenuhi kriteria berdistribusi normal dan homogen, maka selanjutnya dilakukan analisis dengan paired sample t test.

1. Analisis Tes Hasil Belajar

Hasil analisis tes hasil dengan uji paired sample t test menggunakan SPSS disajikan dalam Tabel 5.

Tabel 5. Paired Samples Statistic

\begin{tabular}{ccccc}
\hline Data & Mean & N & Std. Deviation & Std. Error Mean \\
\hline pretest_THB & 27,60 & 20 & 9,456 & 2,114 \\
posttest_THB & 52,30 & 20 & 5,048 & 1,129 \\
\hline
\end{tabular}

Berdasarkan Tabel 5, diketahui rata-rata hasil belajar atau mean pretest sebesar 27,60, dan nilai rata-rata untuk nilai posttest sebesar 52,30, nilai std.deviation (standar deviasi) pada pretest sebesar 9,456 dan posttest sebesar 5,048. Nilai std. error mean untuk pretest sebesar 2,114 dan untuk posttest 1,129. Nilai rata-rata hasil belajar pretest $27,60<$ posttest 52,30 artinya bahwa secara deskriptif ada perbedaan rata-rata hasil belajar pretest dan posttest.

Selanjutnya akan ditampilkan tabel hasil paired samples correlation untuk mengetahui ada tidaknya keterkaitan antara pretest dan posttest untuk tes hasil belajar pada Tabel 6 .
Tabel 6. Paired Samples Correlation

\begin{tabular}{|c|c|c|c|}
\hline & $\mathrm{N}$ & Correlation & Sig. \\
\hline $\begin{array}{c}\text { pretest_THB \& } \\
\text { posttest_THB }\end{array}$ & 20 & 0,299 & 0,200 \\
\hline
\end{tabular}

Pada Tabel 6, tampak jelas bahwa nilai korelasi antara pretest dan posttest sebesar 0,299. dan nilai sig sebesar 0,200 . Artinya, antara pretest dan posttest memiliki keterkaitan. Untuk mengetahui keefektifan dari penggunaan model PBL setting STAD ditinjau dari hasil belajar, maka selanjutnya akan ditunjukkan tabel hasil paired samples test pada Tabel 7.

Tabel 7. Paired Samples Test

$$
\text { Paired Differences }
$$

\begin{tabular}{|c|c|c|c|c|c|c|c|c|}
\hline & \multirow[t]{2}{*}{ Mean } & \multirow[t]{2}{*}{$\begin{array}{c}\text { Std. } \\
\text { Deviation }\end{array}$} & \multirow[t]{2}{*}{$\begin{array}{l}\text { Std. Error } \\
\text { Mean }\end{array}$} & \multicolumn{2}{|c|}{$\begin{array}{l}95 \% \text { Confidence } \\
\text { Interval of the } \\
\text { Difference }\end{array}$} & \multirow[t]{2}{*}{$\mathrm{t}$} & \multirow[t]{2}{*}{$\mathrm{df}$} & \multirow[t]{2}{*}{$\begin{array}{l}\text { Sig. }(2 \\
\text { tailed })\end{array}$} \\
\hline & & & & Lower & Upper & & & \\
\hline $\begin{array}{c}\text { pretest_THB } \\
- \\
\text { posttest THB }\end{array}$ & -24.700 & 9.291 & 2.078 & -29.048 & -20.352 & -11.889 & 19 & 0,000 \\
\hline
\end{tabular}


DOI: https://doi.org/10.24127/ajpm.v10i4.4271

Nilai sig. dari Tabel 7 menunjukkan $0,000<0,05$. Artinya, dari hasil tersebut menunjukkan bahwa model PBL setting kooperatif tipe STAD efektif ditinjau dari hasil belajar mahasiswa. Hasil penelitian ini sejalan dengan hasil penelitian yang pernah dilakukan oleh (Armita, U.Y., Marsigit, 2016) yang menyatakan bahwa model PBL setting STAD efektif ditinjau dari prestasi.

2. Analisis Disposisi Matematis

Berikut akan disajikan Tabel 8 uji paired sample t test.

Tabel 8. Paired Samples Statistic

\begin{tabular}{ccccc}
\hline Data & Mean & $\mathrm{N}$ & Std. Deviation & Std. Error Mean \\
\hline pretest_Dis & 106,00 & 20 & 7,820 & 1,749 \\
posttest_Dis & 118,10 & 20 & 10,156 & 2,271 \\
\hline
\end{tabular}

Berdasarkan tabel 8, diketahui ratarata disposisi matematis atau mean pretest sebesar 106,00, dan nilai ratarata untuk nilai posttest sebesar 118,10, nilai std.deviation (standar deviasi) pada pretest sebesar 7,820 dan posttest sebesar 10,156. Nilai std. error mean untuk pretest sebesar 1,749 dan untuk posttest 2,271. Nilai rata-rata disposisi matematis pretest $106,00<$ posttest 118,10 artinya bahwa secara deskriptif ada perbedaan rata-rata disposisi matematis pretest dan posttest.

Selanjutnya akan ditampilkan Tabel 9 untuk mengetahui ada tidaknya keterkaitan antara pretest dan posttest untuk disposisi matematis.

Tabel 9. Paired Samples Correlation

\begin{tabular}{lccc}
\hline & N & Correlation & Sig. \\
\hline $\begin{array}{c}\text { pretest_Dis \& } \\
\text { posttest_Dis }\end{array}$ & 20 & 0,309 & 0,184 \\
\hline
\end{tabular}

Pada Tabel 9 tampak jelas bahwa nilai korelasi antara pretest dan posttest sebesar 0,309. Sedangkan untuk nilai sig adalah sebesar 0,184 . Artinya, antara pretest dan posttest memiliki keterkaitan. Untuk mengetahui keefektifan dari penggunaan model PBL setting kooperatif tipe STAD ditinjau dari disposisi matematis, maka selanjutnya dilakukan uji paired samples test. Nilai sig. 2_tailed dari tabel 10 menunjukkan $0,000<0,05$. Artinya dari hasil tersebut menunjukkan bahwa model PBL setting STAD efektif ditinjau dari disposisi matematis mahasiswa.

Berdasarkan hasil yang diperoleh dalam penelitian ini, menunjukan bahwa Problem based learning (PBL) sebagai suatu model pembelajaran efektif dalam meningkatkan hasil belajar dan kemampuan disposisi matematis siswa. Kolaborasi kelompok kecil membuat siswa mampu menggabungkn pemikirannya untuk memecahkan masalah yang diberikan di kelas (Meke, et. al., 2018) (Albab, Wanabuliandari \& Sumaji, 2021). Lebih lanjut, PBL mampu meningkatkan minat mahasiswa terhadap proses pembelajaran, sehingga mereka memberikan perhatian lebih dan meningkatkan aktivitas belajar (Meke \& Wondo, 2020) (Albab, Wanabuliandari \& Sumaji, 2021).

Selain peningkatan minat belajar siswa, rasa percaya diri siswa dalam menyelesaikan masalah serta kemampuan komunikasi yang baik mampu ditingkatkan dalam proses pembelajaran matematika menggunakan Problem based learning (Ramdan, et. al., 2018) (Meke \& Wondo \& Meke, 2021).. Hal ini mendukung peningkatan 
tingkat kemampuan disposisi matematis mahasiswa.

Lebih lanjut, metode STAD juga memberikan peningkatan hasil belajar dan kemampuan disposisi matematis mahasiswa. STAD mampu meningkatkan kemampuan berpikir kritis siswa sehingga membuat siswa mampu untuk memecahkan masalah yang diberikan dalam proses pembelajaran matematika (Supratman, Sirad \& Putri, 2021). Selain itu, STAD mampu meningkatkan kemampuan pemahaman matematis siswa dan pemecahan masalah matematis yang mendukung akan meningkatnya hasil belajar dan kemampuan disposisi matematis siswa (Farida, 2014; Mashuri, Jahring \& Nasruddin, 2020).

\section{KESIMPULAN DAN SARAN}

Hasil analisis data penelitian ini menunjukkan bahwa penggunaan model problem based-leraning (PBL) seting STAD dikatakan efektif diukur dari perolehan hasil belajar mahasiswa dan kemampuan disposisi matematis. Hal ini dibuktikan dengan nilai sig. sebesar 0,000 untuk hasil belajar dan disposisi matematis.

Berdasarkan hasil penelitian ini, diberikan beberapa rekomendasi, antara lain kepada para pendidik untuk melaksanakan pembelajaran dengan menerapkan model PBL setting kooperatif tiep STAD. Hal ini dikarenakan pembelajaran ini terbukti efektif ditinjau dari hasil belajar dan disposisi matematis. Hal lain yang harus diperhatikan, yaitu kontrol waktu yang tepat supaya dapat berjalan sesuai yang direncanakan. Saran untuk penelitian selanjutnya adalah memperluas materi yang digunakan dalam penelitian, sehingga memungkinkan generalisasi yang lebih luas.

\section{DAFTAR PUSTAKA}

Albab, R. U., Wanabuliandari, S. \& Sumaji. (2021). Pengaruh model problem based learning berbantuan aplikasi gagung duran terhadap kemampuan pemecahan masalah siswa. AKSIOMA: Jurnal Program Studi Pendidikan Matematika, 10(3), 1767-1775. https://doi.org/10.24127/ajpm.v10i 3.3969

Ali, R., Hukamdad, D., Akhter, A., \& Khan, A. (2010). Effect of Using Problem Solving Method in Teaching Mathematics on the Achievement of Mathematics Students. Asian Social Science, 6(2).

https://doi.org/10.5539/ass.v6n2p6 7

Armita, U.Y., Marsigit, M. (2016). The Effectiveness PBL of STAD and TGT Type In Terms of The Achievements, Critical Thinking, and Self-Efficacy. 4(1), 1-11.

Chen, W. H. (2013). Development of Teaching and Learning Materials for Geometry through Problembased Learning Model. Sains Humanika, 63(2). https://doi.org/10.11113/sh.v63n2. 161

Choridah, D. T. (2013). Peran Pembelajaran Berbasis Masalah Untuk Meningkatkan Kemampuan Komunikasi Dan Berpikir Kreatif Serta Disposisi Matematis Siswa Sma. Infinity Journal, 2(2), 194. https://doi.org/10.22460/infinity.v2 i2.35

Farida, N. (2014). Eksperimentasi Model Pembelajaran Kooperatif Tipe Student Teams Achievement Divisions (STAD) Menggunakan Metode Pemecahan Masalah Ditinjau Dari Sikap Kreatif Peserta Didik. Aksioma. 3(1). 34-39. 
DOI: https://doi.org/10.24127/ajpm.v10i4.4271

http://dx.doi.org/10.24127/ajpm.v3 i1.379

Husnidar., Ikhsan, M., \& Rizal, S. (2014). Penerapan Model Pembelajaran Berbasis Masalah untuk Meningkatkan Kemampuan Berpikir Kritis dan Disposisi Matematis Siswa. Jurnal Didaktik Matematika, 1(1), 71-82. https://doi.org/10.24815/jdm.v1i1. 1243

Ismawati, D., \& Prasetyo, I. (2020). Efektivitas Pembelajaran Menggunakan Video Zoom Cloud Meeting pada Anak Usia Dini Era Pandemi Covid-19. Jurnal Obsesi : Jurnal Pendidikan Anak Usia Dini, $5(1)$, 665. https://doi.org/10.31004/obsesi.v5i 1.671

Jailani, J., Sugiman, S., \& Apino, E. (2017). Implementing the problembased learning in order to improve the students' HOTS and characters. Jurnal Riset Pendidikan Matematika, 4(2), 247. https://doi.org/10.21831/jrpm.v4i2. 17674

Kurniyawati, Y., Mahmudi, A., \& Wahyuningrum, E. (2019). Efektivitas problem-based learning ditinjau dari keterampilan pemecahan masalah dan kemandirian belajar matematis. Jurnal Riset Pendidikan Matematika, 6(1), 118-129. https://doi.org/10.21831/jrpm.v6i1. 26985

Mahmudah, W., \& Triyana, I. W. (2018). Pengembangan Buku Ajar untuk Mendukung Pembelajaran Model Think-Pair-Share pada Mata Kuliah Teori Bilangan. APOTEMA : Jurnal Program Studi Pendidikan Matematika, 4(2), 7783.

Mahmuzah, R., Ikhsan, M., \& Yusrizal.
(2014). Peningkatan Kemampuan Berpikir Kritis Dan Disposisi Matematis Siswa Smp Dengan Menggunakan Pendekatan Problem Posing. Didaktik Matematika, 1(2), 43-53.

https://doi.org/10.24815/dm.v1i2.2 076

Mashuri, S., Jahring \& Nasruddin. (2020). Student Teams Achievement Divisions (Stad) dengan Pendekatan Realistic Mathematics Education (RME) Terhadap Kemampuan Pemahaman Matematis. AKSIOMA. 9(4), 909-916. https://doi.org/10.24127/ajpm.v9i4. 2979

Meke, K. D. P. et al. (2018). The Effectiveness of Problem-based Learning Using Manipulative Materials Approach on Cognitive Ability in Mathematics Learning. J. Phys.: Conf. Ser. 1097012135

Meke, K. D. P. \& Wondo, M. T. S. (2020). Pengembangan Perangkat Pembelajaran Model Problem Based Learning Melalui Penggunaan Bahan Manipulatif. Jurnal Kependidikan: Jurnal Hasil Penelitian dan Kajian Kepustakaan di Bidang Pendidikan, Pengajaran dan Pembelajaran. 6(3). 588-600. https://doi.org/10.33394/jk.v6i3.28 61

NCTM. (2000). Principles and Standards for School Mathematics. United States of America: The National Council of Teachers of Mathematics, Inc.

Nurmila, W. O., Sudia, M., \& Prajono, R. (2019). Pengaruh Model Pembelajaran Kooperatif Tipe Student Team Achievement Division Terhadap Hasil Belajar Matematika Siswa Kelas VII SMP 
DOI: https://doi.org/10.24127/ajpm.v10i4.4271

Kesehatan Mandonga. Jurnal Pendidikan Matematika, 10(1), 112-123.

Ramdan, Z. M. (2018). Analisis Self Confidence Terhadap Kemampuan Pemecahan Masalah Matematis Siswa SMK Pada Materi Barisan dan Deret. AKSIOMA. 7(2) 171179.

http://dx.doi.org/10.24127/ajpm.v7 i2.1335

Sarmiati, S., Kadir, K., Bey, A., \& Rahim, U. (2019). Pengaruh Motivasi Belajar Dan Dukungan Sosial Terhadap Hasil Belajar Matematika Siswa Kelas VIII SMP Negeri 2 Kusambi. Jurnal Pendidikan Matematika, 10(1), 77. https://doi.org/10.36709/jpm.v10i1 .5646

Supratman, Sirad, L. O. \& Putri. A. (2021). Kemampuan Berpikir Kritis Matematis Menggunakan Student Team Achievement Division dan Learning Together. AKSIOMA. 10(2). 1284-1292. https://doi.org/10.24127/ajpm.v10i 2.
Wicaksono, M. A., \& Agustyaningrum, N. (2018). Efektifitas Pendekatan Ctl Dan PBL Dengan Setting Kooperatif Tipe Stad Ditinjau Dari Kemampuan Literasi Matematis Siswa. Cahaya Pendidikan, 4(1), 23-35.

Wondo, M. T. S. \& Meke, K. D. P. (2021). Analisis Pengaruh Sikap Percaya Diri Siswa Dalam Pembelajaran Matematika Menggunakan Model PBL Berbantuan Bahan Manipulatif. Jupika: jurnal pendidikan matematika. 4(1). 11-21. https://doi.org/10.37478/jupika.v4i 1.894

Yusuf, Yunisrina Qismullah; Natsir, Yuliana \& Hanum, Lutfia. (2015). A Teacher's Experience in Teaching with Student TeamsAchievement Division (STAD) Technique. International Journal of Instruction, 8(2). 99-112 